\title{
Antibiotic Resistance and Antibiotic Resistance Genes Among Edwardsiella Tarda Isolated from Fish
}

\author{
Ezzat Mahmoud ${ }^{1}$, Reham M.El-Tarabili' ${ }^{1}$, Esawy A.M. ${ }^{2}$ and \\ Nehal Elmasry ${ }^{1}$ \\ ${ }^{1}$ Department of Bacteriology, Immunology, and Mycology, Faculty of \\ Veterinary Medicine, Suez Canal University, Ismailia, Egypt. \\ ${ }^{2}$ Animal Health Research Institute, Mansoura branch
}

Corresponding author: (Reham M. El-Tarabili),

rehameltrabely@gmail.com, https://orcid.org/0000-0001-8273-2747

\begin{abstract}
Edwardsiella tarda is a common fish pathogen, causing significant septicemic diseases in fish. This study was carried out to investigate prevalence of E. tarda among Tilapia zilli at EL manzla lake, Dakahlia governorate and characterize the isolates phenotypically and genotypically in addition to detection of multi-drug resistance genes (B-lactames genes and plasmid-mediated quinolone resistant genes by PCR assay. Therefore, (100) samples of Tilapia zilli collected from different localities. Fish samples were subjected to clinical and post-mortem examination then bacteriological examination from liver, kidney and spleen. The suspected isolates were characterized by cultural and morphological characters, some conventional biochemical tests and API 20E system then by PCR assay. Eighteen \% isolates were characterized as $E$. tarda. Furthermore, detection of antimicrobial resistance genes by PCR, the recovered isolates harbored blaSHV and blaOXA-1 with a prevalence of $50 \%$ and $25 \%$, respectively with no detection of $a a c\left(6^{\prime}\right)-I b-c r$ and qepA genes in examined isolates. The results of antibiotics sensitivity showed resistance to Nalidixic acid, Lincomycin, Amoxicillin and Norfloxacin and most of isolate were found to be sensitive to Florfenicol and Neomycin.55.6\% of recovered isolates showed resistance to three antibiotic classes and $27.7 \%$ of recovered isolates showed resistance to four antibiotic classes and considered as MDR. The emergence of MDR-strains represents a threat-alarm and PCR is very rapid method for identification of E. tarda isolates which may be helpful in control of Edwardsiellosis.
\end{abstract}


Keywords: Edwardsiell tarda, Tilapia zilli, PCR and Antibiotic resistance genes

\section{Introduction}

Edwardsiella is enteric pathogen includes strains of three species (E. tarda, E. ictaluri and E. hoshinae). E. tarda is primarily a pathogen of fish associated with fish gangrene, emphysematous putrefactive disease of catfish, red disease of eels (Evans et al., 2011). E. tarda is mainly cause of a dangerous systemic disease, Edwardsiellosis which is one of the most important bacterial diseases in fish and it causes mass mortality in the various populations and age groups of fish in freshwater and marine fishes of both farmed and wild population all over the world (Enany et al., 2018). E. tarda is a Gram-negative, short, rodshaped bacterium of about $1 \mathrm{~cm}$ in diameter and $2-3 \mathrm{~cm}$ in length (Evans et al., 2011). E. tarda strains isolated from various geographical sources exhibit little variation in the phenotypic characters (Austin and Austin, 2007) and several studies have demonstrated a wide degree of intraspecific diversity in the isolates from the different geographic regions and host species (Nucci et al.,2002 and Wang et al., 2011).

E.tarda has been recognized as a normal guest of a wide range of animals, including fish, reptiles, crustaceans, chickens and warm- blooded animals as human and contains essential virulence factors which increase bacterial survival and disease in hosts (Castro et al., 2016 and Park et al., 2012). E. tarda strain possess several virulence and toxin secretion associated genes which illustrate to some extent its ability to survive within phagocytic cells and to infect a wide range of hosts due to a highly virulent and multidrug resistant strain (Verjan et al., 2013). Pathogenesis of E. tarda is multifactorial and several potential virulence factors have been recognized to contribute to the infection process have been reported (Mohanty and Sahoo, 2007). Also, it is well known that diagnosis of a particular infection depends on detection and identification of its causative agent (Das et al., 2014).

Nowadays, one of the main threats to public health is the antibiotic resistance (WHO, 2002). Multi-drug resistant (MDR) was defined as resistance to only one agent in three or more antimicrobial classes. (Basak, et al.,.2016). Several previous investigations revealed the emergence of multidrugresistant bacterial pathogens from different origins especially fish that increases the need for new natural immunostimulants 
and antimicrobial alternatives to the commonly used old antimicrobial agents (EL-Sayed et al., 2019; Abouelmaatti et al., 2013; Algammal et al., 2020a; Algammal et al., 2020b; Algammal et al., 2020c; Algammal et al., 2021). This work was carried out to isolate and characterize E. tarda from brackishwater fish Tilapia zilli in Dakahlia governorate, Egypt. In the current study we detect the presence of E. tarda, determine antibiotic sensitivity and screened the presence of antimicrobial resistance genes of E. tarda isolated from diseased, dead and healthy fishes using molecular technique of conventional PCR.

\section{Materials and methods}

\section{Fish sampling:}

A total number of 100 of brackishwater fish of Tilapia zilli (healthy, diseased and morbid)) were collected randomly from EL-Manzla in Dakhlia governorate, Egypt during the period from April 2019 to April 2020. Samples were transported directly in plastic bags to the microbiological department of animal health research institute in EL-Mansoura branch to be full clinical, postmortem and bacteriological examination.

\section{Clinical and postmortem examination}

Fish were examined clinically for the presence of external and internal lesions according to (Schaperclaus et al.,1992) The examined fish were placed on right side. Sterilization of the skin of fish by $70 \%$ ethyl alcohol. The first cut was made in front of the anus through the abdominal wall with blunt sterile Scissors. The second cut was made perpendicular to the first directly behind the branchial cavity and the third cut was from the anus to the head parallel to middle line where the abdominal wall was removed and the internal organs become visible and examined for detection of any abnormalities as change in color, size, hemorrhages ascetic fluid and other abnormalities. fish were examined in a sterile manner using a three-line.

\section{Bacteriological examination}

Samples from kidney, liver and spleen were aseptically inoculated on tryptic soya broth (Oxoid, UK) and incubated at $25-30^{\circ} \mathrm{C}$ for $24 \mathrm{hrs}$. then inoculated on SalmonellaShigella agar (SS agar; Oxoid CM0099) incubated at $35^{\circ} \mathrm{C}$ for 24- 28 hrs. according to (Bergey's et al., 2005). For purification and further identification, recovered isolates streaked on TSA slope and incubated at $37^{\circ} \mathrm{C}$ for $24 \mathrm{hrs}$. All recovered isolate s morphologically were detected with Gram's stain and biochemically according to. (Austin\&Austin.,2007) and by 
using the analytical profile index of API20E system (Buller,2004).

Antibiotic susceptibility test for E. tarda:

The sensitivity test was done on examined isolates of $E$. tarda using disc diffusion method according to (Finegold and martin.1982) using various antimicrobial agents:

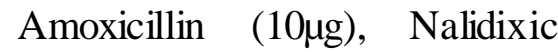

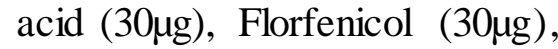

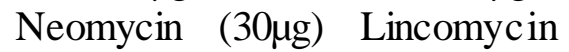

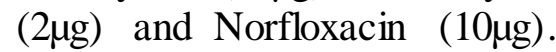
The inhibition zone diameter was measured and interpreted according to (NCCLS, 2007). Isolates showed resistance to more than two different antimicrobial classes were multiple drug resistant (MDR).

Detection of antimicrobial resis tance genes by polyme rase chain reaction

The DNA was extracted using QIAamp DNA mini-Kit Primers (Catalogue no. 239035),USA) and used for the detection of Edwardsiella tarda antibiotic resistance related genes to $\beta$ lactams (bla $a_{S H V}$ and bla $\left.a_{O X A} l\right)$, Fluroquinolones $\left(a a c\left(6^{\prime}\right)-I b-c r\right.$ and qepA (Metabion, Germany) as shown in (Table 1). Separation of amplified products by electrophoresis on $1.5 \%$ agarose gel (Applichem, Germany, $\mathrm{GmbH}$ ) and photographing gels by gel documentation system (Alpha Innotech, Biometra).

\section{Statistical analysis}

The obtained findings were analysed using the Chi-square test with SAS software, version 9.4, SAS Institute, Cary, NC, USA) (Significance-level; $\mathrm{P}<$ $0.05)$.

\section{Results}

Clinical and postmortem examination of fish

Samples represented Tilapia zilli were randomly collected and analyzed. based on the type of fish, the most clinical signs observed in the examined Tilapia zilli were the appearance of abdominal distension, hemorrhage on the surface of the body, congestion of the fins, skin ulcers and congested vent. Accumulation of the ascitic fluid and congestion of the internal organs, including the liver, gallbladder, spleen and kidney, occurred internally. As shown in the (Fig. 1a,b).

Prevalence of E.tarda in the fish and Their distributions in Different Internal Organs

All examined strains were reported as Edwardsiella tarda. Under microscope, the bacteria appeared as Gram-negative, short, rod-shaped bacterium. The bacteria grew well Salmonella shigella agar appear as small transparent with black center on TSA. All recovered isolates were oxidase negative and biochemically homogenous. E.tarda were positive for Indole, 
Methyl Red, Catalase, H2s to different used antimicrobial. production , glucose In present study, all recovered fermentation and reduction isolates showed resistance to nitrate to nitrite but negative for Lactose fermentation, sucrose, Urease, Voges - Proskauer . Also, the presence of E. tarda, identified using API20 E as shown in Fig.(2). The results exhibited that 18 isolates recovered from (zero from healthy fish ,10 from diseased fish and 8 from mourbid fish ) as shown in table (2) and highest distribution of $E$. tarda was in liver (60\%) then kidney (40\%) then spleen $(0 \%)$. Statistically, there is no significant difference in distribution of $E$. tarda among different organs.

Seasonal Variation of $E$. tarda.

Recovered strains of E. tarda were detected during spring, summer and autumn, while in winter not detected in any samples. The summer season showed the highest prevalence with $58.3 \%$ then the spring season with $25 \%$, finally autumn $16.7 \%$. Statistically, there is no difference in seasonal variation of E. tarda.

Antibiotic Sensitivity of recove red $E$. tarda strains:

E. tarda isolates vary in their antimicrobial sensitivity pattern Nalidixic acid, Lincomycin, Amoxicillin and Norfloxacin and most of isolate were found to be sensitive to, Florfenicol and Neomycin. Statistically, there is a significant difference $(\mathrm{P}<$ $0.05)$ in the resistance and susceptibility of the recovered $E$. tarda strains to various antimicrobial agents as shown in table (3). in the present study, $55.6 \%$ of the recovered isolates showed resistance to three antibiotic classes and $27.7 \%$ of recovered isolates showed resistance to four antibiotic classes were multidrug resistant (MDR)

\section{Molecular characterization of} E. tarda is olates

Two isolates of representative four isolates (2/4) showed positive amplification of $392 \mathrm{bp}$ fragment specific for $b l a_{S H V}$ with a total percentage of $50 \%$, one (1/4) isolate showed positive amplification of $619 \mathrm{bp}$ fragment specific for bla $a_{O X A 1}$ with a total percentage of $25 \%$, no recovered isolates detect $a a c(6)-I b-c r$ and qepA amplified at 113 and 403 bp fragment respectively, as shown in Fig $(3,4,5,6)$ 
Table (1): Oligonucleotide primers sequences of genes among recovered isolates

\begin{tabular}{|c|c|c|c|c|}
\hline Gene & Sequence & $\begin{array}{l}\text { Actual cycle } \\
35 \text { cycles }\end{array}$ & $\begin{array}{l}\text { Amplified } \\
\text { product }\end{array}$ & Reference \\
\hline \multirow{2}{*}{$\begin{array}{l}\operatorname{aac}\left(6^{\prime}\right)- \\
I b-c r\end{array}$} & CCCGCTTTCTCGTAGCA & \multirow{2}{*}{$\begin{array}{l}\text { Denaturation: } 94^{\circ} \mathrm{C} / 30 \mathrm{sec} \\
\text { Annealing: } 52^{\circ} \mathrm{C} / 30 \mathrm{sec} \\
\text { Extension: } 72^{\circ} \mathrm{C} / 30 \mathrm{sec}\end{array}$} & \multirow{2}{*}{$113 \mathrm{bp}$} & \multirow{2}{*}{$\begin{array}{l}\text { Lunn } e t \\
a l ., 2010\end{array}$} \\
\hline & TTAGGCATCACTGCGTCTTC & & & \\
\hline \multirow{2}{*}{ blaSHV } & AGGATTGACTGCCTTTTTG & \multirow{2}{*}{$\begin{array}{c}\text { Denaturation: } 94^{\circ} \mathrm{C} / 30 \mathrm{sec} \\
\text { Annealing: } 54^{\circ} \mathrm{C} / 40 \mathrm{sec} \\
\text { Extension: } 72^{\circ} \mathrm{C} / 40 \mathrm{sec} \\
\end{array}$} & \multirow{2}{*}{$392 \mathrm{bp}$} & \multirow{4}{*}{$\begin{array}{l}\text { Colom et } \\
\text { al., } 2003\end{array}$} \\
\hline & ATTTGCTGATTTCGCTCG & & & \\
\hline \multirow{2}{*}{ blaOXA-1 } & ATATCTCTACTGTTGCATCTCC & $\begin{array}{l}\text { Denaturation: } 94^{\circ} \mathrm{C} / 30 \mathrm{sec} \\
\text { Annealing: } 54^{\circ} \mathrm{C} / 40 \mathrm{sec}\end{array}$ & \multirow{2}{*}{$619 \mathrm{bp}$} & \\
\hline & AAACCCTTCAAACCATCC & Extension: $72^{\circ} \mathrm{C} / 45 \mathrm{sec}$ & & \\
\hline \multirow{2}{*}{ qерA } & CGTGTTGCTGGAGTTCTTC & \multirow{2}{*}{$\begin{array}{c}\text { Denaturation: } 94^{\circ} \mathrm{C} / 30 \mathrm{sec} \\
\text { Annealing: } 54^{\circ} \mathrm{C} / 40 \mathrm{sec} \\
\text { Extension: } 72^{\circ} \mathrm{C} / 45 \mathrm{sec}\end{array}$} & \multirow{2}{*}{$403 \mathrm{bp}$} & \multirow{2}{*}{$\begin{array}{l}\text { Cattoir et } \\
\text { al., } 2008\end{array}$} \\
\hline & CTGCAGGT ACTGCGTCATG & & & \\
\hline
\end{tabular}

Table 2. prevelance of Edwardsiella tarda in accordance to fish status:

\begin{tabular}{|l|c|c|c|c|}
\hline Fish & Apparently healthy & Diseased & morubid & Total \\
\hline $\begin{array}{l}\text { No of examined } \\
\text { sample }\end{array}$ & $\mathbf{2 0}$ & $\mathbf{3 0}$ & $\mathbf{5 0}$ & $\mathbf{1 0 0}$ \\
\hline $\begin{array}{l}\text { No of isolated } \\
\text { E.tarda }\end{array}$ & zero & 10 & 8 & $\mathbf{1 8}$ \\
\hline
\end{tabular}

Table 3. Antibiotic sensitivity of recovered E. tarda strains

\begin{tabular}{|l|c|c|c|c|c|c|}
\hline \multirow{2}{*}{$\begin{array}{c}\text { Specific tested } \\
\text { antibiotic }\end{array}$} & \multicolumn{6}{|c|}{ Interpretation } \\
\cline { 2 - 7 } & \multicolumn{2}{|c|}{ Sensitive } & \multicolumn{2}{c|}{ Intermediate } & \multicolumn{2}{c|}{ Resistance } \\
\cline { 2 - 7 } & $N$ & $\%$ & $N$ & $\%$ & $N$ & $\%$ \\
\hline Amoxicillin & 0 & 0 & 2 & 11.2 & 16 & 88.8 \\
\hline Neomycin & 11 & 61.1 & 2 & 11.2 & 5 & $r 7.7$ \\
\hline Norofloxacin & 4 & 22.2 & 4 & 22.2 & 10 & 55.6 \\
Nalidixic acid & 3 & 16.6 & 8 & 44.4 & 7 & 38.9 \\
\hline Lincomycin & 4 & 22.2 & 2 & 11.2 & 12 & 66.6 \\
\hline Florfenicol & 11 & 61.6 & 3 & 16.6 & 4 & 22.2 \\
\hline
\end{tabular}




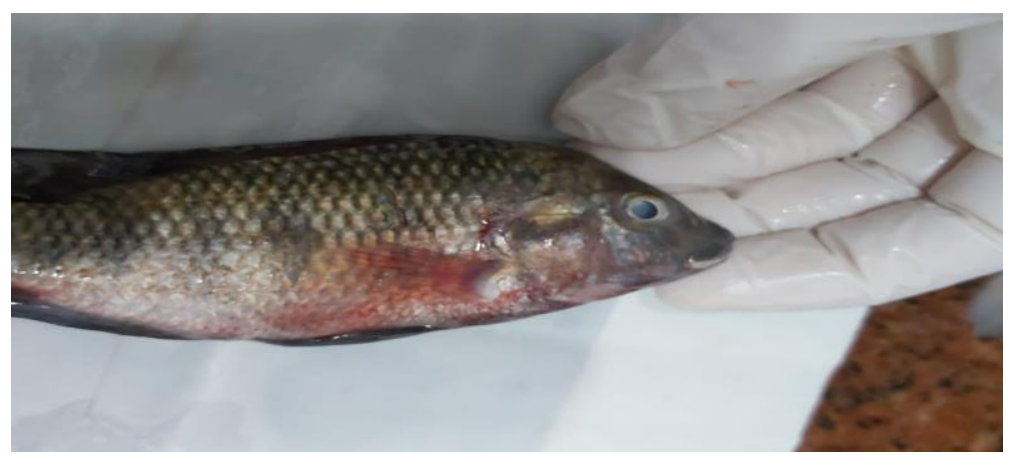

Figure 1a. Naturally infected Tilapia zilli with E. tarda showing, external hemorrhages and congested fins and gills.

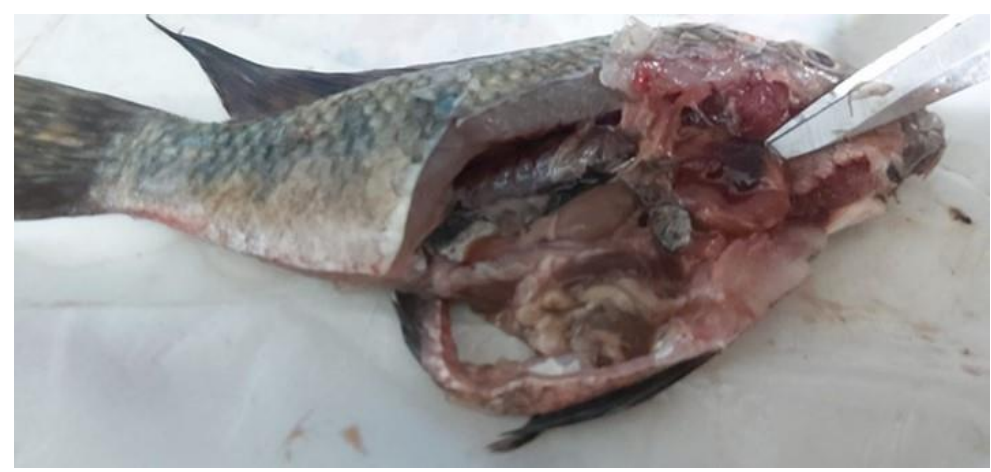

Figure 1 b. Naturally infected Tilapia zilli with E. tarda showing hemmorhage with congested liver

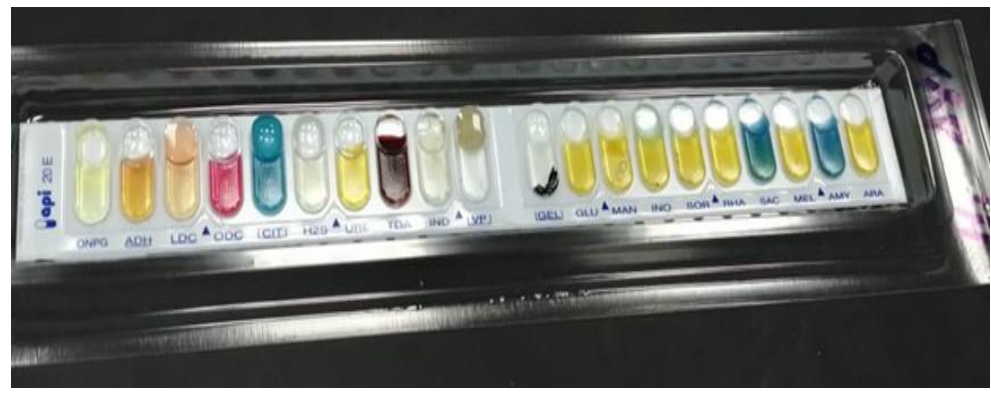

Figure 2. Biochemical identification of the isolates by using API 20E. 


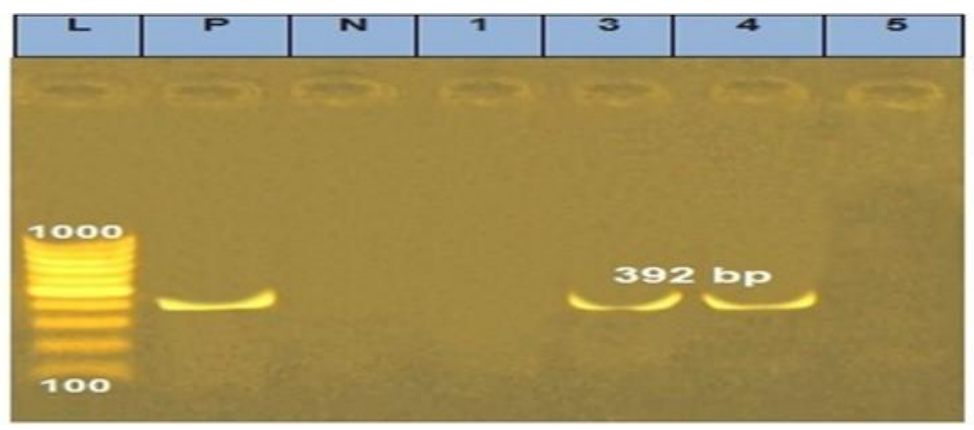

Figure 3. Agarose gel electrophoresis showing MDR gene of $E$. tarda isolates using primer set for blaSHV gene (392bp).

LaneL: 100-1000bp ladder. P: control positive. $\quad$ N: control negative.

Lanes3, 4: E. tarda isolates Positive the blaSHV gene.

Lanes1, 5: E. tarda isolates Negative the blaSHV gene

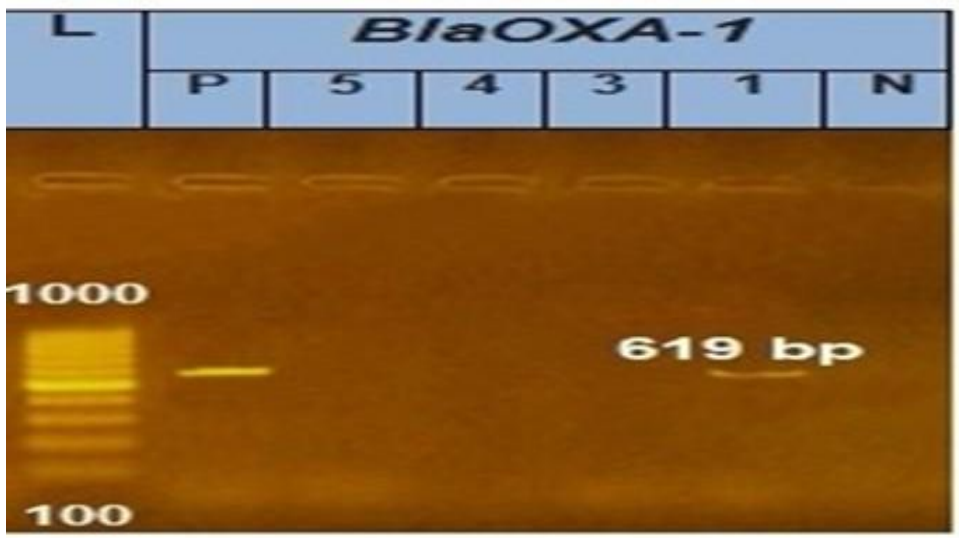

Figure 4. Agarose gel electrophoresis showing MDR gene of E. tarda isolates using primer setfor blaOXA-1 gene (619bp).

LaneL: 100-1000bp ladder. P: control positive. N: control negative.

Lanes 1: E. tarda isolates Positive for the blaOXA-1 gene

Lanes 3, 4,5: E. tarda isolates Negative for the blaOXA-1 gene. 


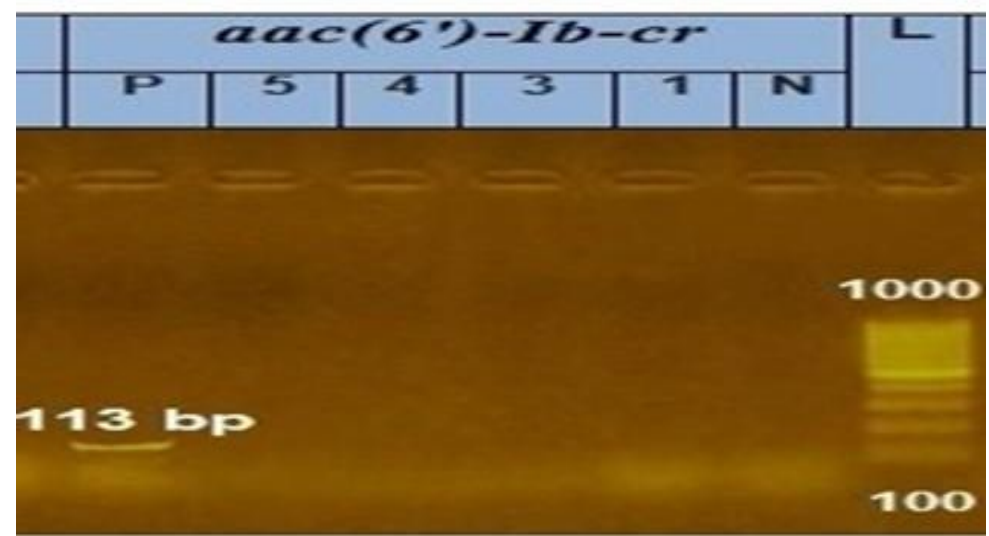

Figure 5. Agarose gel electrophoresis of MDR gene of E. tarda isolates using primer set for aac(6-)-Ib-cr gene (113bp).

LaneL: 100-1000bp ladder. P: control positive. $\quad N$ : control negative.

Lanes1, 3, 4, 5: E. tarda isolates Negative for the aac(6-)-Ib-cr gene.

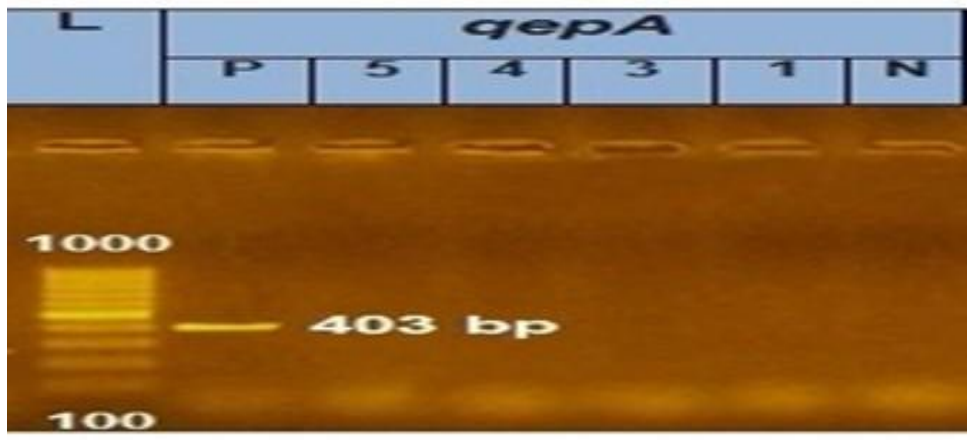

Figure 6. Agarose gel electrophoresis of MDR gene of E. tarda isolates using primer set for qepA gene (403bp).

LaneL: 100-1000bp ladder. P: control positive. $\quad N$ : control negative.

Lanes1, 3, 4, 5: E. tarda isolates Negative for the qepA gene.

\section{Discussion}

Edwardsiellosis is one of the most important bacterial diseases in fishes causing massive mortalities in the various populations and age groups of fish consequently high economic losses (Plumb, 1993 and Jun and Yin, 2006). In the current study, the prevalence of
E. tarda infection among the examined Tilapia zilli was $18 \%$ agree with results of (Korni et al., 2012) who recorded that prevalence of Edwardsiellos is among the cultured Nile Tilapia in spring season at Beni-Suef governorate was $13.33 \%$ and higher than (Ali etal., 2008) who reported that incidence of $E$. 
tarda among the diseased Tilapia zilli at Beni-Suef Governorate was $3.7 \%$. Our results also were disagreed with (Abd El-Mageed et al, 2002) who recorded that incidence of E. tarda in Tilapia zilli collected from different localities in Egypt was $0 \%$ The difference in prevalence of $E$. tarda may be attributed to the difference in water temperature, stocking density, water quality and/or location of the study.

Examination of Tilapia zilli infected with E. tarda revealed number of the clinical signs as abdominal distension, hemorrhages on the body surface, congestion of the fins, presence of skin ulcers and congested vent. Internally, there were accumulation for the ascitic fluid and congestion of internal organs including liver, spleen and kidney. These clinical signs and post-mortem lesions were similar to those reported by (Kubota et al., 1981; Eissa and Yassien 1994; Galal et al, 2002; Saad El-Deen et al., 2005; ElDeeb et al., 2006; Ramadan et al., 2009; Yu et al., 2009 and Hashiem and Abd El-Galil ,2012).

Multidrug resistance could be partly attributed to the inadequate dose, extensive use and sub-active concentration of the drug used in fish farms. Furthermore, widespread use of antibiotics in medical, veterinary, agricultural and aquacultural settings as prophylactic measures and growth promoters have resulted in proliferation of antibiotic resistant genes in horizontal gene pool (Meervenne et al., 2012). Our results detected that the recovered isolates showed resistance to nalidixic acid, Lincomycin, amoxicillin and Norfloxacin and this agree with those reported by (Noor ELDeen et al., 2017 ;Nagy et al., 2018) and most of isolate were found to be sensitive to, florfenicol and neomycin. (Ahamad et al., 2013; Anyanwu et al.,2014; Thangapalam Jawahar Abraham et al.,2015; Pankaj Kumar et al., 2016). These resistance results may be attributed to mutations in the gyrase or to poisomerase antibiotic genes. resistance genes or by horizontal gene transfer of antibiotic resistance determinants (Poole,2004) and (Sorum,2006).

Plasmid mediated quinolone resistance (PMQR) has been shown to play an important role in resistance not only to quinolones, but also B-lactamase and aminoglycosides. In fact, quinolones resistant genes represent one of the most important PMQR mechanisms and frequently carried along with B-lactamase on the same plasmids also aac (6-)-Ib-cr genes. qерA was identified 
PMQR gene encoding efflux pump (Yamane et al.,2007) was detected in Edwardsiella isolates resistant to quinolones. DNA sequencing of $q e p A$ revealed that the gene includes three alleles of qipao (qерA1, qерA2, qерA3), (Cattoir et al.,2008 and wang et al., 2015). In the present work qepA gene could not be identified in any isolates of edwardsiella and disagree with (Liu et al., 2011) who found qepA gene in isolates of E. tarda. Quinolone resistance genes are widely distributed among bacteria (Flach et al.,2013). In this study aac(6-)-Ib-cr genes were investigated using specific primers and PCR, could not be detected in any one of the isolates and this results are in disagreement with these results recorded by $(S u d u$

al.,2018)who isolate 11 out of 30 isolates of E.tarda from fish in japan, (Huang et al., 2012 and Yu et al.,2012)who identified this gene in one isolate and mentioned that this gene was located on large plasmid. While (Liu et al., 2011) mentioned that quinolones resistant genes were acquired from chromosomal genes in bacteria and are usually associated with mobilizing or transposable elements on plasmids.

The high levels of resistance to the $\beta$-lactam antibiotics in several Gram-negative bacteria has been attributed to their intrinsic resistance, often chromosomal mediated and transferable to new generations (Kümmerer, 2009). on the other hand, bla OXA-1 was present in one isolate only with a percentage of $(25 \%)$ and our results detect $b l a_{S H V}$ with a percentage of $(50 \%)$ disagree with (Kees et al., 2008). Who recorded $0 \%$ and $25 \%$, respectively in E. tarda while disagree with (Goudarzi et al., 2013) who could not detect $b l a_{S H V}$ genes in isolates and (Shahcheraghi et al., 2010) found $b l a_{S H V}$ genes among $6 \%$ of 200 isolates.

\section{Conclusion}

Edwardsiellosis infection leads to high morbidity and mortality rate resulting great economic losses. The total prevalence of $E$. tarda in brackishwater fishes is high may be due to pollution and stress factors so that overcrowded, bad environmental condition, bad water quality and high organic matter in fish farms. E. tarda has also public health significance in people engaged in fishery industry and those depend on fish products for their annual income. Overuse or miss use of antibiotics increase Edwardsiella resistance to most antibiotics. PCR method can use as an important technique in the diagnosis of antibiotics resistance genes of MDR E.tarda isolates aac(6-)-Ib-cr, $q n r A, b_{S H V}, \quad b l a_{O X A-1}, q e p A$ - 
based techniques are used increasingly in foodmicrobiology research as they are well developed and when applied as culture confirmation tests, they are reliable, fast and sensitive which measure epidemics occurrence and subsequently decreasing the economic losses.

\section{Refrences}

Abd El-Mageed, A. A.; Khalid, A. M. and Shaheen. (2002). Studies on some types of bacteria and fungi isolated from fish. M.V.Sc. Thesis, Fac. of Vet. Med., Banha Univ., Egypt.

Abouelmaatti, R. R., Algammal, A. M., LI, X., MA, J., Abdelnaby, E. A. and Elfeil, W. M. (2013): Cloning and analysis of Nile tilapia Toll-like receptors type-3 mRNA: Centr. Eur. J. Immunol; 38 (3): 277282.

\section{Ahamad, D. B.,}

Punniamurthy, N., Kumar, V. S., Malmarugan, S., Suresh, R., Ranganathan, V., \& Purushothaman, V. (2013). Outbreak of bacterial haemorrhagic septicaemia in fresh water carps in Thanjavur Region of Tamil Nadu. Advanced BioTech, 12(7), 1215.

Algammal A, Hetta HF, Elkelish A, Alkhalifah D, Hozzein W, Batiha G, El Nahhas N, Mabrok M. (2020a) Methicillin-Resistant
Staphylococcus aureus (MRSA): One Health Perspective Approach to the Bacterium Epidemiology, Virulence Factors, Antibiotic-Resistance, and Zoonotic Impact. Infect Drug Resist.;13: 3255-3265. https://doi.org/10.2147/IDR.S27 2733.

Algammal, A. M., Mabrok, M., Sivaramasamy, E., Youssef, F. M., Atwa, M. H., El-Kholy, A. W., ... \& Hozzein, W. N. (2020b) Emerging MDRPseudomonas aeruginosa in fish commonly harbor $o p r \mathrm{~L}$ and toxA virulence genes and blaTEM, blaCTX-M, and tetA antibioticresistance genes. Scientific Reports 10, 15961. https://doi.org/10.1038/s41598020-72264-4.

Algammal, A. M., Hetta, H. F., Batiha, G. E., Hozzein, W. N., El Kazzaz, W. M., Has hem, $H$. R., ... \& El-Tarabili, R. M. $(\mathbf{2 0 2 0 c})$. Virulence-determinants and antibiotic-resistance genes of MDR-E. coli isolated from secondary infections following FMD-outbreak in cattle. Sci Rep 10, 19779.

Algammal, A.M.; Hashem, H.R.; Alfifi, K.J.; Hetta, H.F.; Sheraba, N.S.; Ramadan, H.; El-Tarabili, R.M. (2021). atpD gene sequencing, multidrug resistance traits, virulencedeterminants, and antimicrobial resistance genes of emerging XDR and MDR-Proteus mirabilis. Sci. Rep. 11, 1-15, 
doi:10.1038/s41598-021-88861-w. Ali, A. H., Radwan, I. A., Ali, W. M., \& Hassan, W. H. (2008). Microbiological characterization of Edwardsiella and Yersinia microorganisms isolated from diseased Tilapias at Beni-Suef Governorate (Doctoral dissertation, $\mathrm{Ph}$. D. Thesis, Fac. of Vet. Med., Univ. of Beni-Suef, Egypt).

Anyanwu MU, KF Chah and VS Shoyinka. (2014).

Antibiogram of aerobic bacteria isolated from skin lesions of African catfish cultured in Southeast Nigeria. International Journal of Fisheries and Aquatic Studies., 2: 134-141.

Austin, B. and Austin, D. A. (2007). Bacterial

Fish

Pathogens: Diseases of Farmed and Wild Fish. 4 Ed, Praxis Publishing Ltd, Chichester, UK. Basak, S., Singh, P., \& Rajurkar, M. (2016). Multidrug resistant and extensively drug resistant bacteria: A study., Journal of pathogens,2016:4065603.

El-Seedy, F. R., Radwan, I. A., Abd El-Galil, M. A., \& Sayed, H. H. (2015). Phenotypic and Genotypic characterization of Edwardsiell tarda isolated from Oreochromis niloticus and Clarias gariepinus at Sohag Governorate. Journal of American Science, 11(11), 6875.

Garrity, G. M., Bell, J. A., \& Lilburn, T. Bergey's manual of systematic bacteriology. 2005. Class III. Gammaproteobacteria class. nov, 2.

Buller, N.B.(2004).Bacteria from fish and other Aquatic animals:A identification

International practical

Cambridge, Manual.CAB publishing, Oxford shire,UK,361PP.

Castro, N., Toranzo, A. E., B arja, J. L., Nunez, S., \& Magarinos, B. (2006). Characterization of Edwardsiella tarda strains isolated from turbot, Psetta maxima (L.). Journal of fish diseases, 29(9), 541-547.

Cattoir V.; Poirel L. and Nordmann P. (2008). Plasmidmediated quinolone resistance pump qepA2 in an Escherichia coli isolate from France. Antimicrob Agents Chemother., 52:3801-3804.

Clinical and Laboratory Standards Institute (CLSI). Performance standards for antimicrobial susceptibility testing; twenty-fifth informational supplement M100-S26. Wayne, PA: CLSI; 2016.

Colom, K., Pérez, J., Alonso, R., Fernández-Aranguiz, A., Lariño, E., \& Cisterna, R. (2003). Simple and reliable multiplex PCR assay for detection of blaTEM, blaSHV and blaOXA-1 gene in Enterobacteriaceae. FEMS microbiology letters, 223(2), 
147-151.

Das, B. K., Sahu, I., Kumari, S., Sadique, M., \& Nayak, K. K. (2014). Phenotyping and whole cell protein profiling of Edwardsiella tarda strains isolated from infected freshwater fishes. Int. J. Curr. Microbiol. App. Sci, 3(1), 235-247.

Eissa, I. A. M. and Yassien, M.A. (1994). Some studies on EPD among catfish Clariaslazera in Lake manzala ISSN110-2047 Alex. Journal of veterinary Science., 10, 41-48.

EI-Deeb, R. K.; Samaha, H. A. and Khaliel, S. A. (2006). Detection of Edwardsiella species in fish and environmental water by Polymerase Chain Reaction PCR. M.V.Sc. Thesis, Fac. of Vet. Med., Alex. Univ., Egypt.

Enany, M., Shalaby, A., Noor El Deen, A., Wahdan, A., \& El Kattawy, Z. (2018). Characterization of Edwardsiella Species Isolated from Fish by Using Genomic DNA Fingerprinting Technique. Suez Canal Veterinary Medical Journal. SCVMJ, 23(2), 215223.

Evans, J. J., Klesius, P. H., Plumb, J. A., \& Shoemaker, C. A. (2011). Edwardsiella septicaemias. Fish diseases and disorders. Volume 3: viral, bacterial and fungal infections, (Ed. 2), 512-569.

Finegold, M., and Martin, J. (1982).

Diagnostic microbiology, the cv Mosby Company, st. Louis. Toronto. London.USA.

Flach, C. F., Boulund, F., Kris tiansson, E., \& Larsson, D. J. (2013). Functional verification of computationally predicted $q n r$ genes. Annals of clinical microbiology and antimicrobials, 12(1), 1-4.

Galal, N. F.; Soliman, M. K. and Zaky, V. H. (2002). Studies on Edwardsiella infection in some freshwater fish. M.V.Sc. Thesis, Fac. of Vet. Med., Alex. Univ., Egypt.

Goudarzi,

Aghamohammad, H., Has hemi, A., Nikmanesh, B., \& Noori, M. (2013). Distribution of blaTEM, blaSHV and blaCTX-M genes among Escherichia coli isolates causing urinary tract infection in children. archives of clinical infectious diseases Volume 8 , Number 3; Page(s) 1 To 4.

Hashiem, M.A. and Abd ElGalil, M.A.A. (2012). Studie s on Edwardsillosis in Claris gariepinus fish at Sohag Governorate Journal of American Science., 8(4):438444.

Huang, X. Z., Frye, J. G., Chahine, M. A., Glenn, L. M., Ake, J. A., Su, W., ... \& Lesho, E. P. (2012). Characteristics of plasmids in multi-drug-resistant Enterobacteriaceae isolated during prospective surveillance of a newly opened hospital in 
Iraq. PloS one, 7(7), e40360.

Kees, V ; van Pelt, W. and Mevius, D. (2008). First report of qnr genes in Edwardsiella tarda in The Netherlands. Journal of antimicrobial chemotherapy., 61(2), 452-453.

Korni, F. M., Essa, M. A., Hussein, M. M., \& Abd ElGalil, M. A. (2012). Edwardsiellosis in some freshwater fishes (Doctoral dissertation, Ph. D. Thesis, Fac. of Vet. Med., Univ. of BeniSuef, Egypt).

Lee Herman, R., \& B ullock, G. L. (1986). Pathology caused by the bacterium Edwardsiella tarda in striped bass. Transactions of the American Fisheries Society, 115(2), 232235.

Kümmerer, K. (2009). Antibiotics in the aquatic environment- A review - Part II. Chemosphere.,75(4):435-41.

Liu, W. B., Liu, B., Zhu, X. N., Yu, S. J., \& Shi, X. M. (2011). Diversity of Salmonella isolates using serotyping and multiloc us sequence typing. Food microbiology, 28(6), 11821189.

Lunn, A. D., Fàbrega, A., Sánchez-Céspedes, J., \& Vila, J. (2010). Prevalence of mechanisms decreasing quinolone-susceptibility among Salmonella spp. clinical isolates. Int Microbiol, 13(1), 15-20.

Mahmoud E. EL-Sayed, Abdelaze em M. Algammal,
Mohamed E. Aboel-Atta, Mahmoud Mabrok, and Aml M. Emam (2019):

Pathogenicity, genetic typing, and antibiotic sensitivity of Vibrio alginolyticus isolated from Oreochromis niloticus and Tilapia zillii; Revue de Medecine Veterinaire; 170, 4-6, 80-86.

Van Meervenne, E., Van Coillie, E., Kerckhof, F. M., Devlieghere, F., Herman, L., De Gelder, L. S., ... \& Boon, N. (2012). Strain-specific transfer of antibiotic resistance from an environmental plasmid to foodborne pathogens. Journal of Biomedicine and Biotechnology. Mohanty, B. R. and Sahoo, P. K. (2007). Edwardsiellosis in fish: a brief review. J. Bioscience., 32:1331-1344.

Nagy, E., Fadel, A., AlMoghny, F. A., \& Ibrahim, M. S. (2018). Isolation, Identification and Pathogenicity Characterization of Edwardsiella tarda Isolated from Oreochromis niloticus Fish Farms in Kafr-Elshiekh, Egypt. Alexandria Journal for Veterinary Sciences, 57(1).

NCCLS Standards for Antimicrobial Susceptibility Tests (2007). Laboratory Medicine, 14(9), 549-553.

Noor El Deen, A. I. E., \& ElGohary, M. S. (2017). Molecular Characterization of Edwardsiella tarda bacteria causing sever mortalities in 
cultured Oreochromis niloticus fish with treatment trials. International Journal of current Research, Vol 9, Issue, 05, pp. 50962-50969.

Nucci, C., Da Silveira, W. D., da Silva Correa, S., Nakazato, G., Bando, S. Y., Ribeiro, M. A., \& De Castro, A. P. (2002). Microbiological comparative study of isolates of Edwardsiella tarda isolated in different countries from fish and humans. Veterinary microbiology, 89(1), 29-39.

Pankaj, K., Harresh, A., and Thangapalam., J. A. (2016). Prevalence of Edwardsiella tarda in commercially important finfish and shellfish of Bihar and West Bengal, India. Journal of Coastal Life Medicine, 4(1), 3035.

Shirajum Monir, Shuvho Chakra Borty, Nazneen Bagum1, Md. Khalilur Rahman, Md. Alimul Islamand Yahia Mahm( 2016). Identification of pathogenic bacteria isolated from diseased stinging catfish, Shing (Heteropneustes fossilis) cultured in greater Mymensingh, Bangladesh Bengal, India. Journal of Coastal Life Medicine., 4(1): 30-35

Park, S. B., Aoki, T., and Jung, T. S. (2012). Pathogenesis of and strategies for preventing Edwardsiella tarda infection in fish. Veterinary research., 43(1), 67.
Plumb, J. A. (1993). Edwardsiella septicaemia. In: Inglis, V.; Roberts, R. J. and Bromage, N. R. (Eds): Bacterial diseases of fish. pp. 61-79, Blackwell Scientific publication, Oxford.

Poole, K. (2004). Effluxmediated antimicrobial resistance. Journal of Antimicrobial Chemotherapy, 56(1), 20-51.

Ramadan, H. K.; et al. (2009). Bacteriological studies on Edwardsiella organisms of fish in El Fayoum Governorate. M.V.Sc. Thesis, Fac. of Vet. Med., Cairo Univ., Egypt.

Schäpe rclaus, W. (1992). Fish diseases (Vol. 1). CRC Press.

Shacheraghi, F., Shakibaie, $M$. R., and Noveiri, H. (2010). Molecular identification of ESBL Genes blaGES-blaVEB blaCTX- M blaOXA-blaOXA-4, blaOXA-10 and blaPER-in Pseudomonas aeruginosa strains isolated from burn patients by PCR, RFLP and sequencing techniques. Int J Biol life Sci., 3(6), 138-42.

Sørum, H. (2006). Antimicrobial drug resistance in fish pathogens. In F.M. Aarestrup (ed.), Antimicrobial resistance in bacteria of animal origin. American Society for Microbiology Press., Washington, DC, pp. 213-238 Stock, I., and Wiedemann, B. (2001). Natural Antibiotic Susceptibilities of Edwardsiella 
tarda, E. ictaluri, and E. hoshinae. Antimicrobial agents and chemotherapy., 45(8), 22452255.

Sudu, M. P, et al. (2018). Antibiotic Resistance and Virulence-Associated Gene Profiles of Edwardsiella tarda Isolated from Cultured Fish in Japan. Turkish Journal of Fisheries and Aquatic Sciences., 19(2), 141-147.

Abraham, T. J., Mallick, P. K., Adikesavalu, H., \& Banerjee, S. (2015). Pathology of Edwardsiella tarda infection in African catfish, Clarias gariepinus (Burchell 1822), fingerlings. Fisheries \& Aquatic Life, 23(3), 141-148.

Verjan, C. R., Augusto, V., Xie, X., \& Buthion, V. (2013). Economic comparison between Hospital at Home and traditional hospitalization using a simulation-based approach. Journal of Enterprise Information Management. ISSN: 1741-0398.

Wang, Y. M., Wang, Q. Y., Xiao, J. F., Liu, Q., Wu, H. Z., \& Zhang, Y. X. (2011). Genetic relationships of Edwardsiella strains isolated in China aquaculture revealed by repPCR genomic fingerprinting and investigation of Edwardsiella virulence genes. Journal of applied microbiology, 111(6), 1337-1348.

Wang, D., Huang, X., Chen, J., Mou, Y., Li, H., \& Yang, L.
(2015). Characterization of genetic structures of the QepA3 gene in clinical isolates of Enterobacteriaceae. Frontiers in microbiology, 6, 1147.

World Health Organization. (2002). Food Safety Department, World Health Organization. Department of Food Safety, World Health Organization Staff, World Health Organization, \& World Health Organization. Food Safety Programme. Terrorist threats to food: guidance for establishing and strengthening prevention and response systems. World Health Organization.

Yamane, K., et al. (2007). New plasmid-mediated

fluoroquinolone elux pump, QepA, found in an Escherichia coli clinical isolate. Antimicrob. Agents Chemother. 51, 3354 3360. doi: 10.1128/AAC.0033907.

Yin, A. (2006). Cenozoic tectonic evolution of the Himalayan orogen as constrained by a long-strike variation of structural geometry, exhumation history, and foreland sedimentation. Earth-Science Reviews., 76(1-2), 1-131.

Yu, J. H., Han, J. J., Park, K. S., Park, K. H., \& Park, S. W. (2009). Edwardsiella tarda infection in Korean catfish, Silurus asotus, in a Korean fish farm. Aquaculture Research, 41(1), 19-26. 
Yu, J. E., Cho, M. Y., Kim, J. contributes to virulence in fish.

W., \& Kang, H. Y. (2012). Microbial pathogenesis, 52(5), Large antibiotic-resistance 259-266.

plasmid of Edwardsiella tarda

\section{المقاومة للمضادات الحيوية والجينات المقاومة للمضادات الحيوية الادواردسيلا تاردا المعزوله من السمك}

يعتبر ميكروب الادواردسـيلا من الميكروبات التى تسـبب مشــاكل مرضـية خطيرة ونؤثر

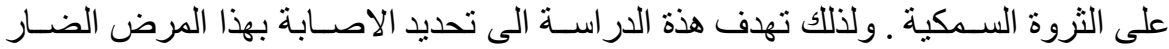

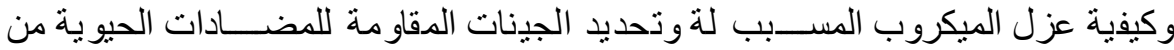

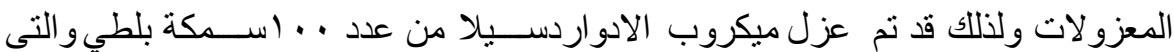

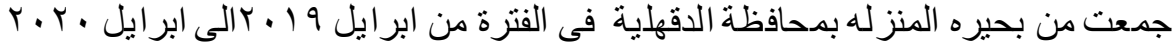

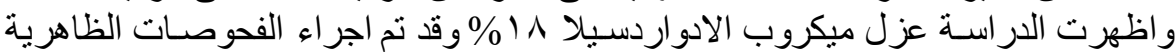

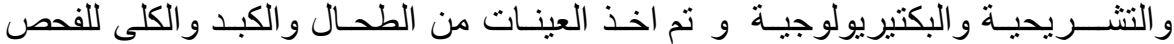

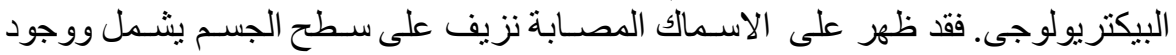

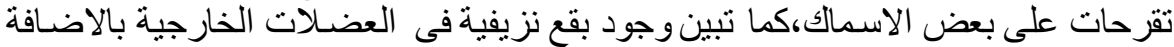

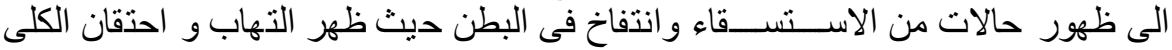

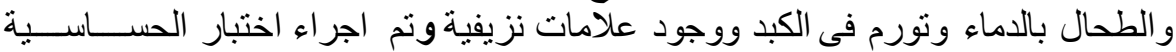

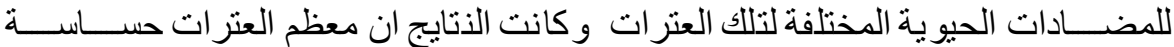

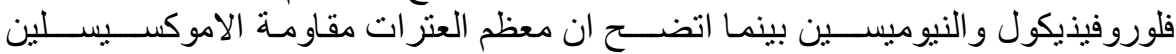

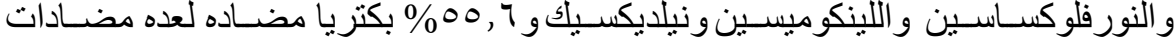

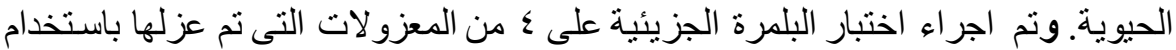

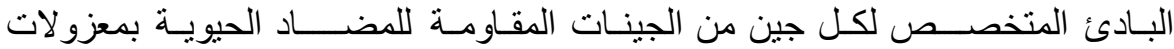

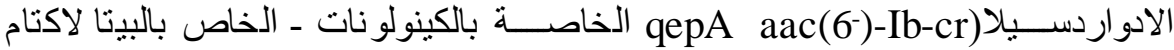

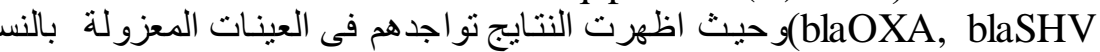

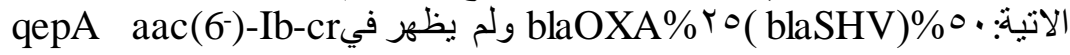

